\title{
Čtení dětem v rodině: výzkum důvodů, parametrů a praktik
}

\author{
Peter Gavora \\ Univerzita Tomáše Bati, Fakulta humanitních studií, Ústav školní pedagogiky
}

Redakci zasláno 11. 10. 2017 / upravená verze obdržena 8. 1. 2018 / k uveřejnění přijato 18. 1. 2018

\begin{abstract}
Abstrakt: Tato empirická studie popisuje situaci čtení dětem v rodině. Cílem bylo zjistit důvody, proč rodiče dětem čtou, frekvenční parametry čtení a čtenářských praktik rodičů a dětí. Výzkumný soubor tvořilo 240 respondentů - rodičů, jejichž děti navštěvovaly mateřskou školu. Výzkumným nástrojem byl dotazník s 52 položkami agregovanými do 17 proměnných. Zjištěné základní parametry čtení dětem jsou vesměs př́iznivé. Většina zkoumaných rodičů čte dětem frekventovaně, dostatečně dlouho a číst začala v průměru před druhým rokem věku dítěte. Děti ve velké většině zkoumaných rodin vlastnily 30 nebo více knih. Byly zjištěny silné rozvojové a emocionální důvody pro dítě. Rodiče při čtení facilitují porozumění, podporují uvažování o postavách prríběhu a stimulují dítě k vlastní naraci obsahu. Slabší je podpora pregramotných činností, tedy aktivit s písmeny, slovy a čísly. Specifický aspekt této studie spočíval v nahlížení na dítě z hlediska aktérství, tedy dítětem iniciovaného a realizovaného konání. Děti z tohoto výzkumného souboru projevovaly o čtení dosti velký zájem, v dyádě čtení se chovaly proaktivně, produkovaly vlastní verze příběhů a své rodiče při čtení monitorovaly.
\end{abstract}

Klíčová slova: pregramotnost, čtení s dítětem, dyáda rodič-dítě, čtenářské praktiky rodiče, čtenářské praktiky dítěte

Čtení dětem je koncept, jenž popisuje praktiky a strategie rodičů při hlasitém čtení dětem. Čte se zpravidla v domácím prostředí, i když existují i jiné situace, např́íklad v čekárně u lékaře nebo při cestě vlakem. Předmětem čtení jsou pohádky, příběhy, básničky nebo jiné žánry, v nichž je text zpravidla doprovázen obrázky. $V$ mnohých rodinách představuje čtení dětem pravidelnou činnost, která má charakter domácí rutiny. Specifickým př́ípadem je domácí čtení dítěti v předškolním věku s ohledem na to, že takové dítě ještě neumí číst. Čtení s dítětem, které již navštěvuje školu, má spíše charakter nácviku techniky hlasitého čtení, tedy převodu kódu psaného na zvukový. Tento druh čtení, přesněji nácviku čtení, není předmětem naší studie. Soustředíme se 
na čtení dětem, které jsou v předškolním věku a jejichž úroveň gramotnosti označujeme jako pregramotnost (Kropáčková, Wildová, \& Kucharská, 2014) nebo vynořující se gramotnost (Lonigan, 2004). Pregramotnost je definována jako „soubor postupně se rozvíjejících předpokladů pro čtení a psaní u dětí v široké době před nástupem do školy. Jedná se o komplex schopností, dovedností, postojů a hodnot potřebných pro zahájení a úspěšné rozvíjení čtenářské gramotnosti..." (Kucharská, 2014, s. 40). Pregramotnost může mít různou úroveň: některé děti již mají elementární znalosti o knize, např. poznají funkci obrázků, směrovost čtení, význam první strany, titulku, slova. Jiné děti rozlišují písmena, umí napsat své jméno, zajímají se o nápisy na budovách a obchodech apod. Pregramotnost je předstupněm počáteční nebo elementární čtenářské gramotnosti, jež se kultivuje ve školním prostředí (Doležalová, 2005; Wildová \& Křivánek, 2009).

\section{Frekvence čtení dětem}

Údaje o frekvenci čtení dětem lze považovat za základní ukazatel péče rodiny o rozvoj pregramotnosti dítěte. Frekvence je důležitý údaj, jelikož dítě potřebuje určité množství čtení, aby působilo rozvojově na jednotlivé komponenty pregramotnosti. Ta je totiž jevem komplexním - není to jedna vlastnost, ale množství souvisejících schopností, dovedností, znalostí i postojů. Výzkum se v první řadě soustředil na kvantitativní zjištění týkající se čtení dětem.

Data nejsou vždy př́znivá: průzkum Národní knihovny ČR na vzorku 1519 dětí ve věku 9-14 let zkoumal vztah dětí ke knihám a knihovnám a zjištoval taktéž procento respondentů, jimž rodiče četli $v$ předškolním věku. Toto procento je velice nízké: $12 \%$ (NÚV, 2014). ${ }^{1} \mathrm{~V}$ jiném průzkumu agentura STEM/MARK (2015) zjistila na vzorku 346 dospělých (vybraných z reprezentativního souboru obyvatelstva) tyto údaje: přibližně $86 \%$ respondentů dětem četlo nebo čte pravidelně, $36 \%$ občas. Nejčastěji čte matka (69\%), mnohem méně často otec (16\%). Ve výzkumu M. Fasnerové (2014) s 206 rodiči, jejichž děti navštěvují mateřskou školu, bylo zjištěno, že téměř všichni (98\%) dětem čtou. Autorka považuje tento údaj zjištěný dotazníkem za nadsazený. Denně čte dětem $37 \%$ rodičů, $51 \%$ rodičů čte několikrát týdně. Pokud jde o data ze Slovenska, průzkum agentury TNS Slovakia (2015) se

Podobný průzkum zorganizovala agentura Gabal Analysis \& Consulting (Gabal \& Václavíková Helšusová, 2003). Jednalo se ovšem o čtení dětí ve věku 10-14 let, ne v předškolním věku. 
182 rodiči vybranými z reprezentativního souboru dospělého obyvatelstva $(\mathrm{N}=1000)$ zjistil, že $49 \%$ rodičů čte dětem vícekrát týdně, $24 \%$ jedenkrát týdně a $27 \%$ rodičů čte méně často, resp. vůbec nečte. Jde o data týkající se dětí ve věku 2-5 let. V internetové anketě organizované pedagogickým vydavatelstvím Enigma (2017) v Nitře odpovědělo 1320 respondentů, kteří dětem čtou. Většinou čtou dětem matky (96\%), pak otcové (3\%), zbytek tvoří prarodiče a starší sourozenci. ${ }^{2}$ Anketa se bohužel neptala na frekvenci čtení.

Pro porovnání uvádíme také data z dalších zemí: v Nizozemsku je procento rodin, které pravidelně čtou dětem, relativně vysoké. Výzkum Duursmové (2014b) shledal, že přibližně $60 \%$ nizozemských rodičủ četlo dětem denně. Šlo o soubor 464 rodičů, kteř́i měli děti ve věku 0 až 5 let. Čtvrtina rodičů věnovala čtení dětem denně $15-20$ minut a převážně četly matky (65 \%). Na rozsáhlém souboru finských dětí $(\mathrm{N}=1436)$ Silinskas a kol. (2012) zjistili, že matky čtou dětem v předškolním věku v průměru 4-6krát týdně, otcové 2-3krát týdně. Russ a kol. (2007) zjistili u reprezentativního souboru rodin v USA, že pouze $48 \%$ rodičủ nebo rodinných příslušníků čte dětem denně. Přibližně $4 \%$ dětí ve věku $4-5$ let rodiče nikdy nečetli. Data se značně lišila podle států unie (rozpětí je 38-68 \%). Frekvence čtení dětem taktéž závisela na sociokulturní a ekonomické charakteristice rodin.

Z uvedených domácích i zahraničních průzkumů je těžké udělat syntézu. Byly použity různé typy výběrů respondentů (stochastický i samovýběr), různé typy otázek a škál. Problematická může být také skutečnost, že dospělí odpovídali na otázky o svém čtení dětem s časovým odstupem nebo že žáci vzpomínali, jak jim rodiče četli v předškolním věku.

Kromě frekvence čtení je důležitým faktorem, $v$ jakém věku dítěte mu rodiče začali číst (Boudreau, 2015). Rané čtení přináší lepší výsledky v rozvoji pregramotnosti než čtení opožděné, i když zde samozřejmě hrají roli i jiné aspekty. Když rodič čte s dítětem od útlého věku, jazykový i obsahový input trvá déle, tudíž je větší i jeho vliv. Někteří rodiče začínají číst dětem velice brzy a jsou i matky, které čtou dítěti před porodem. Podle výzkumu Niklase a kol. (2016a) přibližně 75 \% německých rodičủ začalo číst dětem do 24 měsíců věku. Podobná data byla zjištěna v Austrálii (Niklas et al., 2016b) nebo u amerických rodin převážně bělošského původu (Deckner, Adamson, \& Bakeman, 2006).

Stav ankety ke 22. 9. 2017. 


\section{Jak čtení probíhá}

Kromě frekvence čtení dětem je také důležité posuzovat, jaké postupy rodič při této aktivitě uplatňuje. Výzkum hledal odpověd' na otázku, jaké podpůrné verbální prostředky rodič používá. Dítě podněty potřebuje, jelikož ještě nemá plně rozvinutou pozornost, má slabou autoregulaci i další schopnosti, jež by jeho participaci na čtení posilovaly (Landry \& Smith, 2006). Pozitivní vliv na dítě má kladení otázek rodičem, objasňování, komentování, doplňování obsahu, zaměření pozornosti na vlastnosti knihy apod. (Vandermaas-Peeler et al., 2011). U řeckých matek popsali Melissa-Halikiopoulou a Natsiopolou (2008) 13 různých aktivit, které podporují rozvoj pregramotnosti. Jednalo se kupř. o zaměření pozornosti dítěte na čtení, vysvětlování významu slov, kladení otázek, pozitivní zpětnou vazbu dítěti, opakování slov nebo pomoc při vybavování z paměti. Bohužel zatím nejsou k dispozici výzkumná data o průběhu čtení dětem v českých rodinách.

Další důležitou otázkou je, jaký je efekt uvedených podpůrných aktivit na rozvoj dítěte. Deckner a kol. (2006) ukázali, že frekvence čtení a podpůrné aktivity rodičů související se čtením významně přispívají k rozvoji jazyka dítěte, a to jak na receptivní, tak na produktivní úrovni, a že získané dovednosti přetrvávají i po mnoha měsících. Autoři se soustředili na to, zda matky obrací pozornost k jazykové stránce čtení, zda kladou otázky, vysvětlují význam slov, používají již osvojená slova či poukazují na typografické elementy knihy. Tyto aktivity měly zásadní vliv na rozvoj jazyka dítěte. Podobné pozitivní vlivy čtení rodiči na rozvoj vyjadřování dítěte potvrdil i výzkum Karrase a Braungart-Riekerové (2005). Mengová (2016) prokázala, že rozvinutost slovní zásoby dítěte má vliv na frekvenci čtení rodiče s dítětem. Když se slovní zásoba čtením rozšíríí, vede to rodiče k vyšší frekvenci čtení, a to zpětně k dalšímu rozvoji slovní zásoby.

I když jsou to především matky, jež čtou dětem v předškolním věku, úloha otce není zanedbatelná. Otcové rovněž participují na rozvíjení pregramotnosti dítěte, přičemž jejich příspěvek je často odlišný. Například výzkum Duursmové (2014a) v severoamerických rodinách s nižším příjmem zjistil, že otcové četli dětem méně než matky. Frekvenci ovlivnilo kromě socioekonomických proměnných i to, zda se jednalo o rezidenčního otce (žije v domácnosti s dětmi), nebo ne. $\mathrm{V}$ izraelském výzkumu rodin s různým socioekonomickým statusem (Korat et al., 2008) byly zjištěny rozdíly v obsahu interakce rodičů s dítětem při čtení. Matky kladly dětem méně kognitivně 
náročné podněty než otcové a spojovaly přečtené pasáže s mimojazykovou realitou. Otcové použili podněty s vyšší kognitivní náročností, ale drželi se věrně textu. Rodiče $s$ vyšším socioekonomickým statusem použili otázky s vyšší kognitivní náročností a při čtení častěji využívali mimojazykovou realitu. Styl interakce matek s dětmi byl emocionálně podpưrnější, než jak tomu bylo u otců. Vandermaas-Peeler a kol. (2011) zjistili na americkém vzorku rodičů ze střední a vyšší třídy „překř́ižení rodičů při podpoře čtení. Otcové poskytovali při čtení více vedení dcerám, zatímco matky synům.

$\mathrm{K}$ datům o čtení dětem $\mathrm{v}$ předškolním věku se obrací i výzkum zabývající se deficity ve čtení žáků na základní škole. Zjišt'uje, které předpoklady mohou osvětlit zaostávání dítěte $\mathrm{v}$ dovednosti čtení ve školním věku. Tento výzkum probíhá např́íklad v zemích s různým etnickým složením, přičemž minoritní populace je handicapována také nedokonalou znalostí majoritního jazyka, nepříznivým sociálním prostředím nebo špatnými materiálními podmínkami domova, např. u černošských či portorikánských rodin v USA (Hammer et al., 2007; Jarret, Hamilton, \& Coba-Rodrigues, 2015) nebo u dětí s poruchami řeči/komunikace (Boudreau, 2015). Na základě těchto zjištění vznikly i projekty na podporu čtení v rodinách zaměřené na vysvětlování významu pregramotnosti a důležitosti čtení dětem v předškolním věku a strategií interakce rodičů s dětmi při čtení.

\section{Participace dítěte při čtení}

Druhým členem dyády čtení s rodičem je dítě. Nemusí být vždy jen pasivním posluchačem předčítání matkou či otcem. Reaguje neverbálně i verbálně a zapojuje se do interakce s rodičem. Obsah a intenzita zapojení mohou být různé, ale stěží si lze představit situaci, kdy by dlouhodobě vůbec neprobíhalo.

Tuto angažovanost dítěte při čtení vyjadřujeme konceptem aktérství (agency). Obecně tento koncept ukazuje, že člověk není produktem prostředí, nýbrž na toto prostředí aktivně působí, dělá autonomní rozhodnutí a realizuje je. Bandura (2001, 2006) definuje aktérství jako lidskou schopnost ovlivňovat průběh událostí vlastní činností. Lidé jsou aktéry svých zkušeností spíše než jejich svědky. Být aktérem znamená záměrně ovlivňovat vlastní fungování a životní okolnosti. Lidé jsou proaktivní, regulují vlastní chování a reflektují je. 
Pokud jde o dítě, tak tento koncept harmonizuje s novějším pojetím dítěte a dětství vymezeným tzv. novou sociologií dětství (James \& Prout, 1990; James, 1996; Uprichard, 2008). Dítě není nedokonalý nebo „neúplný“ dospělý a dětství se nechápe jako období, v jehož průběhu se dítě přibližuje stavu dospělosti a získává status „úplnosti“ (Lee, 1998). Činnost dítěte má charakter aktérství, když dítě koná z vlastní vůle, intencionálně, a daná činnost má pro něj smysl. Aktérství dítěte může vystupovat v nejrůznějších situacích doma i mimo domov, existuje tedy i při dyadickém čtení s rodičem. Je však nutno citlivě rozlišovat, zda daná situace a konání mají či nemají znaky aktérství. Když dítě odpovídá matce na otázku, není to aktérská činnost. Žádáli však matku, aby dále četla, nebo začne-li z vlastní iniciativy komentovat obsah čteného, toto naopak aktérstvím je. Je totiž přítomná intencionalita dítěte a existuje předpoklad, že toto komentování má pro dítě smysl. Aktérská činnost dítěte může mít různou míru intencionality a trvání, proto lze hovořit o různém stupni dětského aktérství při domácím čtení.

Výzkum dětského aktérství při čtení s rodičem je dosud velice málo rozvinut. Důraz se klade spíše na rodiče a na jejich čtení s dítětem. V našem výzkumu založeném na kvalitativním interview s rodiči, kteří měli děti $v$ předškolním věku, jsme odhalili šest různých aktivit dítěte vykazujících atributy aktérství: výběr knihy, dotazování na obsah čteného, komentování obsahu, expanze obsahu, vyjednávání a monitorování postupu rodiče při čtení (Gavora, 2016). Jelikož se koncept dětského aktérství při čtení s rodičem ukázal jako potenciálně efektivní, přijali jsme jej coby jednu ze složek výzkumu.

\section{Cíl výzkumu}

Cílem výzkumu bylo popsat čtení dětem $\mathrm{v}$ rodině, kde je přítomno dítě předškolního věku. Předmětem zkoumání bylo (a) rodinné prostředí, (b) rodič, který dítěti čte, (c) dítě, kterému je čtení určeno. Jak jsme již vysvětlili, čtení rodiče provází více či méně frekventovaná interakce obou aktérů s důležitými funkcemi - udělat text pro dítě srozumitelným, udržet jeho pozornost, rozvíjet jeho pregramotnost a formovat pozitivní postoje ke čtení a knihám.

Konkrétně si studie kladla za cíl získat údaje o frekvenci čtení, důvodech čtení dětem a o čtenářských praktikách rodičů a dítěte (17 proměnných). Kromě toho bylo cílem získat demografické údaje o rodině respondentů (8 proměnných). Jednotlivé proměnné jsou uvedeny při popisu výzkumného souboru a výzkumného nástroje. 
Výzkum tudíž usiloval o získání relativně širokého obrazu čtení dětem v rodině u souboru respondentů, přičemž vycházel z koncepce dokumentované již v předešlém výzkumu: čtení dětem není jednostrannou záležitostí rodiče, dítě je při čtení aktivním členem dyády (Gavora, 2016). Dítě při čtení používá postupy a strategie, jež naplňují jeho potřeby a zájmy, tudíž je jeho chování aktérské (Bandura, 2001; Mayall, 2010).

\section{Výzkumný nástroj}

Výzkumný nástroj tvořil dotazník, jehož záměrem bylo zachytit kvantitativní charakteristiky čtení $s$ dítětem v rodině, důvody rodičů číst $s$ dětmi a specifické druhy čtenářských praktik rodičů a dětí. Dotazník se skládal z 52 položek a měl následující strukturu:

a) Demografické vlastnosti rodiny zahrnovaly pohlaví respondenta a jeho dítěte, počet dětí v domácnosti, věk dítěte, úplnost rodiny, nejvyšší vzdělání rodičů, zaměstnání rodičủ, celkový hrubý př́ijem domácnosti a rozsah dětského knižního fondu v domácnosti.

b) Parametry čtení dítěti zahrnovaly frekvence čtení dítěti dospělými, frekvence čtení dospělého pro sebe, věk začátku čtení dítěti, trvání čtení dítěti a trvání expozice čtení ${ }^{3}$.

c) Důvody čtení byly sledovány ve třech okruzích. Rozvojový důvod zahrnoval čtení pro rozvoj slovní zásoby, představivosti, paměti, logického uvažování, poznání světa, přípravy na základní školu a vytváření vztahu ke knize (př́klad: „Dítěti čtu, protože to rozvíjí jeho představivost."). Emocionální důvod se týkal citového stavu matky při čtení (př́íklad: „Dítěti čtu, protože je to pro mě radostná chvilka."). Pacifikační důvod se týkal uvolňovací atmosféry při čtení (př́íklad: „Dítěti čtu, protože ho chci uklidnit po rušném dni.").

d) Praktiky rodiče orientované na dítě se skládaly ze tří okruhů. Facilitace porozumění čteného se týkala frekvence vysvětlování významu slov, objasňování situací, konání postav, spojení obsahu textu se zážitky dítěte a vysvětlování důvodu čtení (příklad „Jak často objasňujete dítěti situaci v knize, když máte dojem, že jí nerozumělo?"). Podpora čtenářského uvažování zjištovala frekvenci otázek kladených dítěti o obsahu a též vyprávění

3 Expozice čtení = fyzický věk dítěte mínus věk začátku čtení. 
o přečteném (příklad „Jak často kladete dítěti otázky k postavám příběhu?"). Nácvik pregramotných aktivit zjištoval frekvenci hry rodiče a dítěte s písmeny nebo číslicemi, nácvik psaní písmen/slov a používání tabletu, počítače nebo telefonu dítětem (př́klad „Jak často si s dítětem hrajete hry s písmeny nebo číslicemi?").

e) Čtenářské praktiky dítěte obsahovaly čtyři okruhy. Proaktivní činnost dítěte $\mathrm{v}$ průběhu čtení se zjišt'ovala frekvencí objasňovacích otázek dítěte zaměřených na obrázky a výrazy, dále na jeho komentáře k postavám a ději a na jeho žádosti o kauzální vysvětlení (př́íklad „Jak často klade vaše dítě otázky ,proč??"). Literární produkce dítěte se zjištovala frekvencí vyprávění dítěte podle obrázku, imitace čtení a vymýšlení vlastních příběhů (příklad „Jak často si dítě vymýšlí vlastní příběhy?"). Monitorování rodiče dítětem při čtení se zjištovalo výskytem obracení stránek knihy dítětem, sledováním čtení prstem, opravy rodiče nebo jeho upozorňování (příklad „Jak často dítě sleduje prstem, kde čtete?"). Zájem dítěte o čtení se zjišt'oval frekvencí žádosti dítěte o čtení, žádosti o zvýšení rozsahu čtení a výběr literatury pro čtení (př́íklad „Jak často dítě samo vybírá knihu nebo příběh pro čtení?").

Otázky zjištujuící frekvenci měly pětibodovou škálu od „nikdy“ (1) do „velice často" (5). Odpovědi na položky zaměřené na míru ztotožnění se s tvrzením měly škálu od „nesouhlasím“ (1) do „souhlasím“ (5). Reliabilita částí dotazníku (Cronbachovo Alfa) zároveň s deskriptivními údaji jsou uvedeny v tabulkách 3 a 4. Pokud jde o okruhy důvody čtení, čtenářské praktiky rodiče a čtenářské praktiky dítěte, reliabilita je pro účel nereprezentativní studie přijatelná $(0,831,0,665$ a 0,787$)$. Reliabilita jednotlivých proměnných v rámci těchto okruhů je nižší, jelikož závisí nejen na homogenitě, ale i na počtu položek, jichž v tomto případě bylo méně. Nejvyšší reliabilitu měla proměnná rozvojové důvody rodičů $(0,884)$, jež obsahovala osm položek, nejnižší reliabilitu naopak vykazovala proměnná pacifikační důvody rodičů $(0,583)$, která měla pouze tři položky.

Dotazník byl distribuován rodičům v mateřských školách, které děti respondentů navštěvovaly. Rodičům byl vysvětlen cíl výzkumu a výzkumný charakter zjištování, dotazník byl vyplňován anonymně. 


\section{Výzkumný soubor}

Výzkumný soubor tvořilo 240 respondentů - rodičů ze Zlínského a Moravskoslezského kraje, jejichž děti navštěvovaly mateřskou školu. Tento soubor hodnotíme jako dostupný (convenient sample). Ženy tvořily 89,9\% respondentů, muži 10,1\%. Úplné rodiny představovaly $81,9 \%$ souboru, neúplné $18,1 \%$. Většina rodin, $66,4 \%$, měla jedno dítě, dvě děti mělo $31,5 \%$ rodin, tři děti mělo $1,8 \%$ rodin. Rodiče si mohli vybrat, na kterém ze svých dětí v předškolním věku založí odpovědi v dotazníku. Tyto děti byla ve $44,9 \%$ děvčata, chlapci představovali 55,1\%. Věkové rozpětí dětí bylo $2-6,5$ roků.

Stratifikaci vzdělání a zaměstnání výzkumného souboru zobrazuje tabulka 1. Pokud jde o vzdělání, úroveň našeho výzkumného souboru je poněkud vyšší, než je průměr v ČR, ve kterém je populace se základním vzděláním rozsáhlejší $(17,6 \%)$ a, opačně, s vysokoškolským vzděláním užší $(12,5 \%$; údaje podle ČSÚ, 2011). Věkové složení našeho souboru je ovšem nižší, než reprezentují data ČSÚ. Tabulka ukazuje rovněž značnou proporci chybějících údajů, zejména u zaměstnání, kde se respondenti často vyjadřovali př́liš obecně (např. OSVČ) a nebylo je proto možné kategorizovat.

Tabulka 1

Vzdělání a zaměstnání rodičů výzkumného souboru (v \%)

\begin{tabular}{llcc}
\hline & matka & otec \\
\hline Vzdělání & Základní & 3,3 & 3,3 \\
& Středoškolské & 18,3 & 28,3 \\
& Středoškolské s maturitou & 39,2 & 33,8 \\
& Vysokoškolské & 37,1 & 25,0 \\
& Postgraduální & 0,4 & 2,9 \\
& Chybějící údaje & 1,7 & 2,9 \\
\hline Zaměstnání & Dělník & 5,4 & 11,7 \\
& Řemeslník & 19,2 & 21,7 \\
& Odborník & 19,2 & 20,4 \\
& Vysoce kvalif. odborník & 23,8 & 17,5 \\
& Chybějící údaje & 32,5 & 28,8 \\
\hline
\end{tabular}




\section{$5 \quad$ Výsledky}

\subsection{Základní údaje o čtení v rodině}

Čtení dětem v rodině vytváří důležité předpoklady a stimuly pro rozvoj pregramotnosti a budování vztahu dítěte ke knihám. Proto jsme zjišt’ovali sedm základních údajů, které toto čtení charakterizuje (tabulka 2). První údaj se týká frekvence čtení dítěti. Téměř $44 \%$ rodičủ čte dětem několikrát za týden, 35,5 \% rodičů čte dětem denně. Druhý údaj je podobný zjištění v jiném českém výzkumu (37\%; Fasnerová, 2014). Pravidelné čtení vytváří návyk dítěte ke čtení a pozitivně působí i na jeho postoje k němu, jež pak přetrvávají i do pozdějšího věku. Přibližně sedm procent rodičů v našem souboru ovšem dětem nečte vůbec nebo jenom jedenkrát za měsíc. $V$ těchto rodinách si dítě obtížněji vytvoří zájem o čtení nebo pozitivní postoj ke knize. Kromě frekvence je důležitá i délka trvaní jednoho čtení. 79 \% respondentů v našem souboru čte dětem po dobu 30 až 40 minut. Vzhledem k celodenním povinnostem rodičů je to doba pozoruhodně dlouhá. Na druhou stranu, přibližně jedno procento rodiču čte dětem pět minut, což je pro rozvoj pregramotnosti dítěte velmi málo. U velké většiny rodin vlastní dítě 30 nebo více knih a má na ně zpravidla vymezený prostor. Může si knihy prohlížet a starat se o ně. Tím se vytváři dobrý předpoklad k tomu, aby se kniha stala součástí života dítěte.

$\mathrm{V}$ průměru začali rodiče dítěti číst, když mu bylo méně než dva roky. Někteří respondenti uváděli rovněž čtení od narození (5,5\%). Byly to př́ípady, kdy bylo dítě přítomno, když rodič četl staršímu sourozenci, ale jednalo se i o situace, kdy dítě sourozence nemělo $(2,1 \%)$. Věk zahájení čtení dítěti má velký význam pro rozvoj jeho kognitivních procesů. Delší expozice čtení poskytuje více příležitostí pro rozvoj pregramotnosti, slovní zásoby i dalších kognitivních procesů. Metaforicky to vystihuje název studie Niklase a kol. (2016a) Ranní ptáče dál doskáče. V našem souboru věk zahájení čtení dítěti statisticky významně koreloval s frekvencí čtení $\left(-0,252^{* *}\right)$, trváním jednoho čtení $\left(-0,131^{*}\right)$ a počtem knih, jež dítě vlastní $\left(0,252^{* *}\right)$.

Celkově data u zkoumaných proměnných čtení v našem souboru respondentů ukazují nárůst frekvencí směrem k vyšším, tudíž příznivějším kategoriím. Globální stimulační charakter čtenářského prostředí zkoumaných českých rodin je vesměs pozitivní.

Frekvence a časové údaje zobrazují ovšem jen jednu stránku čtení s dítětem. Pro poznání situace jsou sice důležitá, ale neposkytují plný obraz. Podstatně 
významnější stránkou je, jak rodiče zdůvodňují potřebu čtení, čím se toto čtení naplňuje a jaké jsou konkrétní praktiky rodiče a dítěte při společném čtení.

Tabulka 2

Základní údaje o čtení $v$ rodině

\begin{tabular}{|c|c|c|c|c|c|}
\hline & $\begin{array}{l}\text { Nikdy/ } \\
\text { ojediněle }\end{array}$ & 1x za měsíc & 1x za týden & $\begin{array}{l}\text { Několikrát } \\
\text { za týden }\end{array}$ & Denně \\
\hline Frekvence čtení dítěti & $1,3 \%$ & $5,6 \%$ & $13,9 \%$ & $43,7 \%$ & $35,5 \%$ \\
\hline $\begin{array}{l}\text { Frekvence čtení dítěti } \\
\text { druhým dospělým }\end{array}$ & $18,5 \%$ & $22,7 \%$ & $23,2 \%$ & $29,2 \%$ & $6,4 \%$ \\
\hline $\begin{array}{l}\text { Čtení dospělého pro } \\
\text { sebe }\end{array}$ & $20,1 \%$ & $15,0 \%$ & $20,5 \%$ & $30,8 \%$ & $13,7 \%$ \\
\hline Věk začátku čtení & \multicolumn{5}{|c|}{$M=22,2$ měs.; rozpětí 0-60 měs.; $S D=12,5$} \\
\hline Expozice čtení & \multicolumn{5}{|c|}{$M=31$ měs.; rozpětí $0-72$ měs.; $S D=15: 08$} \\
\hline Trvání čtení & $\begin{array}{l}5 \mathrm{~min} . \\
1,3 \% \\
\end{array}$ & $\begin{array}{c}10-15 \mathrm{~min} . \\
5,6 \% \\
\end{array}$ & $\begin{array}{r}20 \mathrm{~min} \\
13,9 \% \\
\end{array}$ & $\begin{array}{c}30 \mathrm{~min} . \\
43,7 \% \\
\end{array}$ & $\begin{array}{l}40 \mathrm{~min} . \\
35,5 \%\end{array}$ \\
\hline Počet dětských knih & 5 & 10 & 20 & 30 & Nad 30 \\
\hline & $1,7 \%$ & $8,5 \%$ & $21,6 \%$ & $22,5 \%$ & $45,8 \%$ \\
\hline
\end{tabular}

Pozn.: Expozice čtení = fyzický věk dítěte v čase sběrů dat mínus věk začátku čtení.

\subsection{Důvody čtení}

Zkoumání důvodů vedoucích rodiče k tomu, aby dětem četli, nám umožňuje pochopit nejen jejich záměry a aspirace, ale taktéž orientaci jejich úsilí v průběhu čtení. Výzkum se soustředil na tři důležité důvody.

První důvod byl rozvojový - zlepšování kognitivních schopností dítěte (pamět', myšlení, představivost), rozšiřování slovní zásoby, příprava na základní školu, i vytváření pozitivního vztahu ke knize. Jak ukazuje tabulka 3, rodiče uváděli rozvojový důvod coby ten nejdůležitější. Na pětibodové škále se jejich volby blíží nejvyššímu bodu $(M=4,38 ; S D=0,62)$. Uvědomují si tedy rozvojové efekty čtení a hodnotu investice do času stráveného s dítětem při společném čtení. Zahraniční výzkumy zaměřené na čtení rodičů s dítětem potvrdily vliv zejména na rozvoj receptivní slovní zásoby dítěte a na jeho poznání vlastností knihy (Neuman, 1996). Kromě toho tyto výzkumy dokázaly, že rozvojový vztah byl reciproční. Úroveň slovní zásoby získané při čtení s rodičem predikovala rozsah aktivity dítěte při tomto čtení (Meng, 2016). Zajímavý je motiv čtení jako přípravy na základní školu. Anticipace primární 
školy jako vzdělávací instituce založené na kultuře čtení je velice pozitivním prvkem zkoumaných rodin.

Druhý důvod čtení byl emocionální. Rovněž tento důvod považovali rodiče za velmi důležitý. Průměr $(M=4,22 ; S D=0,82)$ stojí vysoce nad středovým bodem použité pětibodové škály. Rodič pocit’oval radost $\mathrm{z}$ chvil strávených spolu s dítětem při čtení a měl potěšení ze společné aktivity. Bez této emocionální složky by společné čtení bylo fádní, nezáživnou událostí. Této emocionalitě však konkuruje pacifikační důvod čtení. Rodiče připravují dítě na spánek tak, že mu čtou. Průměr je sice značně nižší než u předchozího důvodu $(\mathrm{M}=3,17 ; \mathrm{SD}=0,96)$, nicméně pacifikační motiv je v rodině přítomen. Nejtypičtější situace společného čtení je totiž večer po uložení dítěte ke spaní. Rodič oddělí dítě od rušných aktivit a čte, aby dítě upokojil. Večerní situace občas dostávají humornou podobu. Jak ukázal náš předchozí výzkum (Gavora, 2016), rodič při čtení někdy únavou usíná, zatímco dítě se dožaduje jeho plné soustředěnosti.

Celkový průměr hodnocení tř̌i důvodů, jež vedly rodiče ke čtení s dítětem, je dosti vysoký $(M=4,07 ; S D=0,58)$. Rodiče dostatečně reflektují, co je ke čtení $\mathrm{s}$ dítětem vedlo a jaké efekty mohou od tohoto čtení očekávat. Zejména důvod rozvojový a emocionální je silně motivující, vede rodiče ke čtení a udržuje je u něj.

\section{3 Čtenářské praktiky rodiče}

Další zkoumané proměnné mají jiný charakter - týkají se konkrétních činností rodiče provázejících čtení. Když čte dítěti rodič, nedochází jenom k převodu grafického kódu do orálního (na to dostačuje audiokniha). Rodič interaguje s dítětem, sleduje jeho reakce a odpovídá na ně. Typickou aktivitou byla facilitace porozumění čtenému, tedy přiblížení jeho obsahu dítěti. Nerozumí-li dítě textu, uniká mu nejen obsah, ale i smysl čtení. Položky zahrnovaly vysvětlování významu slov nebo slovních spojení, objasňování děje, situace a konání postav, spojování obsahu textu se zážitky dítěte i vysvětlování důvodů čtení. Porozumění obsahu totiž není jen esencí čtení, ale má i další atributy. Situace, děj a postavy nejsou přítomny, dítě o nich jenom slyší, ale nevidí je. Jsou pro něj určitou abstrakcí a úlohou rodiče je tuto abstrakci vysvětlit (do určité míry rodiči napomáhají ilustrace v knížce). Celková frekvence těchto aktivit bohužel nebyla u našich respondentů vysoká, resp. nebyla tak vysoká, jak bychom si práli $(\mathrm{M}=2,97 ; \mathrm{SD}=0,78)$. 
Proměnná podpora čtenářského uvažování se týkala aktivního zapojení dítěte do čteného obsahu. Šlo o kladení otázek dítěti k postavám př́iběhu nebo o žádost o vyprávění obsahu. Pro rodiče to je ovšem náročnější činnost, resp. činnost, která některým rodičům překáží, protože brzdí plynulé čtení. Je to také obtížná činnost pro dítě, takže rodiče na ni mohli rezignovat. To vysvětluje ještě nižší průměr než u facilitace porozumění obsahu $(M=2,88$; $\mathrm{SD}=0,98)$.

Proměnná nácvik pregramotných aktivit obsahovala položky týkající se společné hry rodičů a dítěte s písmeny nebo číslicemi, nácviku psaní písmen/ slov a používání tabletu, počítače nebo telefonu dítětem. Všechny tyto činnosti, iniciované nebo zprostředkované rodiči, považujeme za nácvikové. Představují významný vstup dítěte do světa gramotnosti, včetně elektronické. Aritmetický průměr této proměnné je ovšem nejnižší ze všech zkoumaných činností rodičů $(\mathrm{M}=2,69 ; \mathrm{SD}=0,85)$. Připisujeme to jejich náročnosti, proto je rodič většinou zavádí až ve vyšším věku dítěte. Korelace mezi věkem dítěte a těmito činnostmi byla statisticky velmi významná (od $0,26^{* *}$ do $0,38^{* *}$ ).

Při celkovém pohledu na praktiky rodiče při čtení dítěti konstatujeme relativně nízký průměr $(M=2,84 ; S D=0,59)$. Vysvětlujeme to třemi způsoby, jež se můžou doplňovat. Především kladly zkoumané činnosti vyšší nároky na rodiče, proto byl jejich průměr nižší. Oproti tomu údaje o trvání čtení, jak je zachycuje tabulka 2, byly vesměs příznivé. Jedná se totiž o lehčí činnost, aktivita rodiče je jednodušší. Druhým důvodem může být nízká kompetence rodiče pro jistou činnost. Umění klást otázky, vysvětlovat nebo komentovat děj vyžaduje jisté znalosti, schopnosti, nebo dokonce cit. V zahraničí proto existují programy na zlepšení interakce rodiče s dítětem při čtení (Neuman 1996; Justice \& Pullen, 2003; Sim \& Berthelsen, 2014). Třetí důvod nízkého průměru je snaha rodiče číst nepřerušovaně, tedy neklást dítěti otázky, neposkytovat mu vysvětlení nebo komentáře, protože to zvyšuje dobu čtení daného př́běhu. Rodič je večer unaven a nechce mít čtecí chvilku dlouhou a vysilující.

\section{4 Čtenářské praktiky dítěte}

Ve výzkumu jsme se zaměřili na čtyři druhy čtenářských praktik dítěte, kterým přisuzujeme atribut aktérství. Patř́i k nim zájem o čtení, proaktivní chování dítěte při čtení, literární produkce dítěte a monitorování čtení rodiče (tabulka 4). Zájem o čtení zahrnoval žádosti dítěte, aby rodič četl, vlastní 
volbu knihy nebo příběhu a naléhání na další čtení nebo jeho pokračování ve chvíli, kdy rodič dočetl. Tyto aktivity získaly nejvyšší hodnocení ze všech zkoumaných činností dítěte $(\mathrm{M}=4,11 ; \mathrm{SD}=0,84)$. Na pětibodové škále tento průměr znamená vysokou frekvenci. Dítě se ukázalo jako aktivní člen dyády a jako partner prosazující své záměry. Mělo zájem o obsah čtení i svá oblíbená témata i hrdiny. Na druhou stranu není možno opomenout, že naléhání na další čtení nemuselo vždy být založeno na pohnutkách literárních, nýbrž důvody mohly být pragmatické: dítě zkrátka ještě nechtělo spát.

Proaktivní chování dítěte při čtení zahrnuje otázky dítěte týkající se obrázků v knize, dále otázky k významu neznámých slov a otázky typu proč. Patří sem rovněž vlastní komentář $\mathrm{k}$ ději nebo postavám v prríběhu. Průměr je o něco nižší než u zájmu o čtení, ale je stále dosti vysoký $(M=3,50 ; S D=0,79)$. Dítě tedy představuje aktivního posluchače, který se chce o obsahu čteného dozvědět víc a je přirozeně zvědavý. Pokud jde o jeho komentář k příběhu, tady se z posluchače stává vypravěč, jenž k př́běhu přikládá vlastní poznámky nebo jej doplňuje. Z dotazníků nebylo možné zjistit, jak dlouhý nebo jak propracovaný byl dětský komentář nebo ke kterým elementům příběhu se vztahoval. Aktérství dítěte se nicméně i v této proměnné dostatečné frekventovaně naplnilo.

Dětské aktérství dále vystupuje v činnosti, kterou jsme možná odvážně nazvali literární produkce dítěte. Dítě vypráví vlastní verzi obsahu podle obrázku, vymýšlí si vlastní př́běhy a imituje chování při čtení - obrací stránky a mluví pro sebe $(\mathrm{M}=3,11 ; \mathrm{SD}=0,97)$. Tady již dítě nabývá ještě výraznějších prvků autonomie - v podstatě přesouvá dospělého do role posluchače a samo v situaci dominuje. Jeho vyprávění je možná jednoduché, ale je autorské. Obracení stránek knihy při tom představuje zásadní vizuální prvek manifestující čtenářství. Hlasité čtení, které dítě při listování imituje, není typické ve čtenářském chování dospělého, dospělý čte spíše potichu pro sebe. Na druhou stranu je hlasitost v dětské reprezentaci element zvýrazňující čtenářství - pouhé listování by ještě nemuselo znamenat čtení, tj. zmocnění se obsahu. Obracení stránek knihy dokazuje, že dítě má elementární chápání organizace knihy, totiž sekvenci děje po stránkách. Vyprávění příběhu podle obrázků znamená pochopení asociace mezi orálně podaným př́iběhem, jeho grafickou podobou a jeho obrazovou oporou. Jsou to komponenty znalostí dítěte o knize a tisku (Clay, 2000). Rozsáhlé výzkumy demonstrovaly, že tyto znalosti jsou prediktorem pozdější úrovně čtení ve škole (Sénéchal \& LeFevre, 2003; Sénéchal, 2006; Hindman \& Morrison, 2012). 
Při monitorování čtení rodiče se dítě dostává do ještě aktivnější pozice. Je nejen průvodcem rodiče při jeho předčítání - obrací mu stránky, sleduje čtení prstem (důkaz, že dítě chápe organizaci obsahu do řádků) - ale je také jeho kontrolorem. Opravuje nebo upozorňuje rodiče, když vynechá nebo změní část děje nebo popisu (dítě zná texty nazpamět'). Průměr těchto činností není vysoký $(M=2,45 ; S D=0,96)$, ale naznačuje jistou suverenitu dítěte v partnerství s rodičem, což je velice cenný prvek čtení dětem.

Celkový pohled na frekvenci čtyř sledovaných čtenářských praktik dítěte ukazuje na jistý trend: čím je daná činnost lehčí, tj. méně náročná, tím získala větší frekvenci a, vice versa, obtížné činnosti měly nižší frekvenci. Trend ukazuje nárůst náročnosti fungování dítěte při čtení, a tudíž i pokles jeho frekvence od zájmu o čtení k otázkám a komentářum a pak dále k vlastní produkci. Monitorování rodiče dítětem a kontrola jeho čtení pak reprezentuje vyšší pozici dítěte $\mathrm{v}$ dyádě. $\mathrm{V}$ situaci čtení získává dítě jistou moc nad rodičem. Celkový průměr čtenářských praktik dítěte reprezentovaný čtyřmi proměnnými činí 3,31 (SD =0,61), pohybuje se tedy nad střední hodnotou použité pětibodové škály. Všechny zkoumané proměnné demonstrují aktérství dítěte, tedy jeho intencionální a smysluplnou činnost. Dítě tak nezůstává pasivním členem dyády, ale aktivně interaguje s rodičem, aby dosáhlo svých záměrů a uspokojení svých potřeb.

Tabulka 3

Okruhy a proměnné rodiče ve vztahu k čtení dítěti

\begin{tabular}{lllllc}
\hline Okruhy & Proměnné & M & SD & Alfa & $\begin{array}{c}\text { Počet } \\
\text { položek }\end{array}$ \\
\hline \multirow{2}{*}{ Důvody čtení } & Rozvojové & 4,38 & 0,62 & 0,884 & 8 \\
& $\begin{array}{l}\text { Emocionální } \\
\text { Pacifikační }\end{array}$ & 4,22 & 0,82 & 0,639 & 2 \\
\hline Celkem & 3,17 & 0,96 & 0,583 & 3 \\
\hline \multirow{2}{*}{$\begin{array}{l}\text { Cacilitace } \\
\text { rodiče }\end{array}$} & 4,07 & 0,58 & 0,831 & 13 \\
& $\begin{array}{l}\text { porozumění } \\
\text { Podpora čtenářského praktiky }\end{array}$ & 2,97 & 0,78 & 0,655 & 4 \\
& uvažování & 2,88 & 0,98 & 0,629 & 2 \\
& $\begin{array}{l}\text { Nácvik } \\
\text { pregramotných } \\
\text { aktivit }\end{array}$ & 2,69 & 0,85 & 0,616 & 3 \\
\hline Celkem & & 2,84 & 0,59 & 0,665 & 9 \\
\hline
\end{tabular}

Pozn.: $\mathrm{M}$ = aritmetický průměr; SD = směrodatná odchylka, Alfa = Cronbachův koeficient homogenity. 
Tabulka 4

Čtenářské praktiky dítěte

\begin{tabular}{llllc}
\hline Proměnné & M & SD & Alfa & Počet položek \\
\hline Zájem o čtení & 4,11 & 0,84 & 0,708 & 3 \\
Proaktivní chování & 3,50 & 0,79 & 0,711 & 4 \\
Literární produkce & 3,11 & 0,97 & 0,740 & 3 \\
Monitorování čtení rodiče & 2,45 & 0,96 & 0,590 & 3 \\
\hline Celkem & 3,31 & 0,61 & 0,787 & 13 \\
\hline
\end{tabular}

Pozn.: Zkratky jako u tabulky 3.

\section{Diskuse}

Čtení dětem rodiči sehrává mimořádně důležitou roli při rozvoji pregramotnosti. Tato studie přispívá k pochopení toho, v jakém prostředí se čtení realizuje, jaké důvody $\mathrm{k}$ této činnosti vedou rodiče a jak konkrétně tato činnost probíhá. V základních parametrech čtení dětem můžeme výzkumný soubor hodnotit vesměs příznivě. Většina zkoumaných rodičủ čte dětem frekventovaně, dostatečně dlouho a číst začala v průměru před druhým rokem dítěte. Děti ve velké většině zkoumaných rodin vlastnily 30 nebo více knih. Výzkum nicméně odhalil i rodiny s málo stimulujícím čtenářským prostředím. Dětem vůbec nečte nebo čte ojediněle $1,3 \%$ rodin, někteří rodiče čtou pouze pět minut $(1,3 \%)$, jejich děti mají jenom pět knih $(1,3 \%)$ a rodiče začali číst, až když mělo dítě pět let $(0,8 \%)$. Důvody jsou různé. Na jedné straně jsou to méně příznivé sociální a ekonomické podmínky těchto rodin (knihy jsou drahé, rodiče mají náročné zaměstnání a nemají na dítě čas), na druhé straně to můžou být kulturní postoje a zájmy (vlažný vztah ke knihám). Specifickým důvodem může být taktéž nedostatek informací o významu a efektech čtení dětem $v$ raném věku nebo o tom, jak toto čtení vést. $V$ České republice ovšem probíhá několik akcí zaměřených na propagaci čtení v rodině a rozvoj dětského čtenářství, které tyto informace poskytují. Jedná se např. o projekt Celé Česko čte dětem, do nějž se zapojily knihovny, knihkupectví, mateřské i základní školy, nemocnice, rozhlas i televize. Cílem je vysvětlování významu čtení dětem a jeho podpora. $Z$ dalších projektů lze jmenovat Rosteme s knihou nebo Noc s Andersenem. Z hlediska našich výsledků by se tyto a podobné projekty měly zaměřit nejen na zvyšování zájmu dětí o knihy a čtení, ale taktéž na procesuální stránku čtení, tedy na to, jak má konkrétně čtení probíhat, 
jaké strategie a praktiky mají rodiče $\mathrm{v}$ dyádě čtení $\mathrm{s}$ dítětem používat a jak mají podporovat aktivní vstup dítěte do svého čtení.

Jádro našeho výzkumu tvořilo zjištování důvodů čtení a čtenářských praktik rodiče a dítěte. Byly zjištěny silné rozvojové a emocionální důvody čtení rodiči. U rozvojových důvodů se to ovšem předpokládalo, vždyt' kognitivní, jazykový a gramotnostní rozvoj je základem domácího čtení. Emocionální důvod je však jeho důležitým průvodcem (Justice \& Pullen, 2003). Rodiče facilitují porozumění při čtení, podporují uvažování o postavách příběhu a stimulují dítě k vlastní naraci př́iběhu. Nejslabší je podpora pregramotných činností, tedy aktivit s písmeny, slovy a čísly. Jde sice o herní aktivitu, nicméně tato aktivita má nácvikový charakter. Nižší frekvenci vysvětlujeme tím, že jde v rámci čtení z knihy o „přidanou aktivitu“ kladoucí další požadavky na čas rodiče.

Specifický aspekt této studie byl v nahlížení na dítě z aspektu aktérství, tedy dítětem iniciovaného a realizovaného konání. Př́ijemným zjištěním bylo, že děti tohoto výzkumného souboru mají o čtení velký zájem. Potvrdilo se také jejich proaktivní chování v dyádě s rodičem při čtení. Děti také „literárně“ produkují, a dokonce monitorují své rodiče při čtení.

Vzhledem k omezení rozsahu studie nebylo možné popsat souvislosti mezi demografickými charakteristikami rodiny, čtenářským prostředím a čtenářskými praktikami rodičủ a dětí. Ty budou předmětem jiné studie. Přitom je již ted' zřejmé, že tyto charakteristiky silně ovlivňují čtenářské ukazatele rodiny (Melissa-Halikiopoulou \& Natsiopolou, 2008; Meng, 2016).

Data v tomto výzkumu byla zjišt’ována pomocí dotazníku. I když jeho reliabilita byla přijatelná, jeho validitu jsme zjištovali pouze z obsahového hlediska (face validity). Konstruktovou validitu nebylo kvůli různým typům a různému rozsahu použitých škál možno zjištovat. Vzhledem k použitému výzkumnému nástroji není jasné, jak respondenti v odpovědích reprezentují své reálné chování při čtení v rodině. Otázkou především je, do jaké míry byly tyto odpovědi respondenty nadsazené. To se dá ověřit jenom pozorováním dyády čtení př́mo v rodině nebo pomocí nahrávek tohoto čtení, jak to dělal výzkum Vandermaas-Peelerové a kol. (2011). Ani to však nemusí odstranit problém deformací. Výzkumník nebo kamera $\mathrm{v}$ domácnosti mohou být také zdrojem zkreslení, protože subjekty můžou své chování „hrát“. Jistou oporu $\mathrm{k}$ našim údajům o čtenářském chování dítěte poskytl náš předchozí výzkum založený na interview s rodiči. 
Tento výzkum byl popisem čtení rodičů dětem a čtenářských praktik rodičů a dětí. Širší vhled do problematiky by poskytl výzkumný model proces-produkt, který by zjišt’oval, jak ovlivnily čtenářské praktiky rodičů výkonové parametry dítěte, zejména $v$ kognitivní, jazykové a postojové rovině. V zahraničí je tento model velice rozšířen a má vysokou výpovědní hodnotu. V zahraničí je ovšem k dispozici velké množství standardizovaných nástrojů na diagnostikování posunů ve vývoji charakteristik dítěte souvisejících s pregramotností, které výzkum bohatě využívá (De Jong \& Leseman, 2001; Sènèchal \& LeFevre, 2003; Roberts, Jurgens, \& Burchinal, 2005; Sènèchal, 2006; Hindman \& Morrison, 2012; Duursma, 2014a).

Když dítě navštěvuje mateřskou školu, setkává se čtení v rodině s rozvojem pregramotnosti v této vzdělávací instituci - pak se vlivy obou prostředí mohou posilovat. Rámcový vzdělávací program pro předškolní vzdělávání zahrnuje práci s knihou, především čtení dětem, vysvětlování, rozvoj porozumění textu, reprodukci obsahu a jiné činnosti spjaté se čtením a literárním obsahem. Mateřská škola může nejen rozvíjet pregramotnost dítěte, ale má i potenciál kompenzovat nepříznivé domácí čtenářské prostředí dítěte.

\section{Literatura}

Bandura, A. (2001). Social cognitive theory: An agentic perspective. Annual Review of Psychology, 52(1), 1-26.

Bandura, A. (2006). Toward a psychology of human agency. Perspectives on Psychological Science, 1(2), 164-180.

Boudreau, D. (2015). Use of parent questionnaire in emergent and early literacy assessment of preschool children. Language, Speech, and Hearing Services in Schools, 36(1), 33-47.

Clay, M. (2000). Concepts about print. Auckland: Heinemann.

Deckner, D. F., Adamson, L. B., \& Bakeman, R. (2006). Child and maternal contributions to shared reading: Effects on language and literacy development. Applied Developmental Psychology, 27(1), 31-41.

De Jong, P. F., \& Leseman, P. P. M. (2001). Lasting effects of home literacy on reading achievement in school. Journal of School Psychology, 39(5), 389-414.

Doležalová, J. (2005). Funkční gramotnost - proměny a faktory gramotnosti ve vztazích a souvislostech. Hradec Králové: Gaudeamus.

Duursma, E. (2014a). The effects of fathers' and mothers' reading to their children on language outcomes of children participating in early Head Start in the United States. Fathering, 12(3), 283-302.

Duursma, E. (2014b). Parental bookreading practices among families in the Netherlands. Journal of Early Childhood Literacy, 14(4), 435-458

ENIGMA (2017). Anketa Kto vo vašej rodine číta det'om knižky? Nitra: ENIGMA. 
Fasnerová, M. (2014). Celé Česko čte dětem. Výzkumná zpráva projektu. Olomouc: Pedagogická fakulta UP.

Gabal, I., \& Václavíková Helšusová, L. (2003). Jak čtou české děti? Analýza výsledků sociologického výzkumu. Praha: Gabal Analysis \& Consulting. Dostupné z http://www.adam.cz/ dokumenty/2006/jak-ctou-ceske-deti.pdf

Gavora, P. (2016). Preschool children in book-reading situations with parents. The perspective of personal agency theory. Studia Paedagogica, 21(4), 99-116.

Hammer, C. S., Rodriguez, B. L., Lawrence, F. R., \& Miccio, A. W. (2007). Puerto Rican mothers' beliefs and home literacy practices. Language, Speech and Hearing Services in Schools, 38(3), 216-224.

Hindman, A. H., \& Morrison, F. J. (2012). Differential contribution of three parenting dimensions to preschool literacy and social skills in a middle-income sample. Merrill-Palmer Quarterly, 58(2), 191-223.

James, A. (1996). Childhood identities. Edinburgh: Edinburgh University Press.

James, A., \& Prout, A. (Eds.) (1990). Constructing and reconstructing childhood. Contemporary issues in the sociological study of childhood. London: Falmer.

Jarret, R. L., Hamilton, M.-B., \& Coba-Rodrigues, S. (2015). „So we would all help pitch in.“ The family literacy practices of low income African American mothers of preschoolers. Journal of Communication Disorders, 57, 81-93.

Justice, L. M., \& Pullen, P. C. (2003). Promising interventions for promoting emergent literacy skills: Three evidence-based approaches. Topics in Early Childhood Special Education, 23(3), 99-113.

Karras, J., \& Braungart-Rieker, J. (2005). Effects of shared parent-infant book reading on early language acquisition. Applied Developmental Psychology, 26(2), 133-148.

Korat, O., Ron., R., \& Klein, P. (2008). Cognitive mediation and emotional support of fathers and mothers to their children during shared book-reading in two different SES groups. Journal of Cognitive Education and Psychology, 7(2), 223-247.

Kropáčková, J., Wildová, R., \& Kucharská, A. (2014). Pojetí a rozvoj čtenářské pregramotnosti v předškolním období. Pedagogická orientace, 24(4), 488-509.

Kucharská, A. (2014). Riziko dyslexie. Pregramotnostní dovednosti a schopnosti a rozvoj gramotnosti v rizikových skupinách. Praha: Pedagogická fakulta UK v Praze.

Landry, S. H., \& Smith, K. E. (2006). The influence of parenting on emerging literacy skills. In D. K. Dickinson \& S. B. Neuman (Eds.), Handbook of early literacy research (s. 135-148). New York: The Guilford Press.

Lee, N. (1998). Towards immature sociology. The Sociological Review, 46(3), 458-482.

Lonigan, C. J. (2004). Emergent literacy skills and family literacy. In B. H. Wasik (Ed.), Handbook of family literacy (s. 43-82). Mahwah: Lawrence Erlbaum.

Mayall, B. (2010). Towards a sociology for childhood. Maidenhead: Open University Press.

Melissa-Halikiopoulou, C., \& Natsiopolou, T. (2008). Mothers reading children's books to preschoolers. A Greek study. International Journal of Caring Sciences, 1(2), 74-78.

Meng, C. (2016). Joint book reading and receptive vocabulary: A parallel process model. Infant and Child Development, 25(1), 84-94. 
Neuman, S. B. (1996). Children engaging in storybook reading: The influence of access to print resources, opportunity, and parental interaction. Early Childhood Research Quarterly, 11(4), 495-513.

Niklas, F., Cohrssen, C., Tayler, C., \& Schneider, W. (2016a). Erstes Vorlesen: Der Früher Vogel fängt den Wurm. Zeitschrift für Pädagogische Psychologie, 30(1), 35-44.

Niklas, F., Cohrssen, C., \& Tayler, C. (2016b). The sooner, the better: Early reading to children. SAGE Open I-II.

NÚV. (2014). Stále méně dětí baví čtení. Dostupné z http://www.nuv.cz/publikace/stalemenedeti-bavi-cteni?highlightWords=gramotnost

Roberts, J., Jurgens, J., \& Burchinal, M. (2005). The role of home literacy practices in preschool children's language and emergency skills. Journal of Speech, Language, and Hearing Research, 48(2), 345-359.

Russ, S., Perez, V., Garro, N., Klass, P., Kuo, A. A., Gershun, M., ... Zuckerman, B. (2007). Reading across the nation: A chartbook. Boston: Reach Out and Read National Center.

Sènèchal, M., \& LeFevre, J. (2003). Parental involvement in the development of children's reading skills: A five year longitudinal study. Child Development, 73(2), 445-460.

Sènèchal, M. (2006). Testing the home literacy model: Parent involvement in kindergarten is differentially related to Grade 4 reading comprehension, fluency, spelling, and reading for pleasure. Scientific Studies of Reading, 10(1), 59-87.

Silinskas, G., Lerkkanen, M.-K., Tolvanen, A., Niemi, P., Poikkeus, A.-M., \& Nurmi, J.-E. (2012). The frequency of parents' reading-related activities at home and children's reading skills during kindergarten and grade 1. Journal of Applied Developmental Psychology, 33(6), 302-310.

Sim, S., \& Berthelsen, D. (2014). Shared book reading with small children: Evidence-based practice. Australasian Journal of Early Childhood, 39(1), 50-55.

STEMMARK. (2015). Čtení dětem. Závěrečná zpráva. Praha: STEMMARK. Dostupné z http:// docplayer.cz/16567545-Cteni-detem-zaverecna-zprava-brezen-2015.html

TNS Slovakia. (2015). Čítame det'om? Výsledky prieskumu o čítaní kníh s det'mi vo veku 2-8 rokov. Dostupné z http://www.tns-global.sk/sites/default/files/files/report_citanie_knih.pdf

Uprichard, E. (2008). Children as "being and becomings": Children, childhood and temporality. Children and Society, 22(4), 303-313.

Vandermaas-Peeler, M., Sassine, B., Price, C., \& Brilhart, C. (2011). Mother's and father's guidance behaviours during storybook reading. Journal of Early Childhood Literacy, 12(4), 415-442.

Wildová, R., \& Křivánek, Z. (2009). Základy gramotnosti (počáteční čtenářská gramotnost). In J. Průcha (Ed.), Pedagogická encyklopedie (s. 230-234). Praha: Portál.

\section{Autor}

prof. PhDr. Peter Gavora, CSc., Univerzita Tomáše Bati, Fakulta humanitních studií, Ústav školní pedagogiky, Štefánikova 5670, 76001 Zlín, e-mail: gavora.p@gmail.com 


\title{
Reading to children in the family: An ivestigation of reasons, parametres and practices
}

\begin{abstract}
The study describes home reading situations in Czech families. The purpose was to identify the parents' reasons for reading to children, frequency of reading, and reading practices of parents and children. The sample consisted of 240 respondents - parents whose children attended preschool. A questionnaire of 52 items, which were aggregated to 17 variables, was used to gather data. The basic data about reading to children are favourable. Most of the parents read to children frequently, the reading session is relatively long and they began to read before the child was two years old. Children possess at least 30 books. High averages were identified in developmental and emotional reasons of reading to children. Parents facilitate the child's comprehension of stories, they support thinking about the story characters and stimulate the child to retell the story. However, they infrequently use shared play with letters, words or numbers. The specific perspective of this study was child's agentic behaviour in reading sessions, i.e., the child's ability to initiate and perform intentional behaviour in reading situations. Children were much interested in reading, they demonstrated proactive behaviour, produced independent narrations of the stories, and they were able to monitor their parents' reading aloud.
\end{abstract}

Keywords: preliteracy, reading with child, parent-child dyad, parents' reading practices, child's reading practices

Fasnerová, M. (2018). Prvopočáteční čtení a psaní. Praha: Grada.

Učitelé v praxi i studenti pedagogických oborů prohloubí své znalosti na poli práce se živou abecedou a se slabikářem, naučí se jaký typ slabikáře si vybrat, které pomůcky je možné využívat a jak celkově přistupovat k výuce čtení a psaní. Pozornost je věnována také specifickým poruchám u dětí, jejich příčinám a tomu, jak moc ovlivňují průběh vyučování. Publikace mapuje nejnovější výzkumná šetření, jako jsou například rychlost písma nebo význam nové písemné předlohy Comenia Script. Seznamuje i s výsledky posledního výzkumu, který byl realizován v roce 2016 a týkal se čtenářských kompetencí dětí a žáků v primárním a preprimárním vzdělávání z pohledu pedagogů mateřských a základních škol. 